\title{
Weed management in kharif rice in new alluvial zone of West Bengal
}

\section{K. Ghosh*}

Department of Agronomy, Bidhan Chandra Krishi Viswavidyalaya, Mohanpur, Nadia741252 (West Bengal), India

\section{K. A. Chowdary}

Department of Agronomy, Bidhan Chandra Krishi Viswavidyalaya, Mohanpur, Nadia741252 (West Bengal), India

\section{B. C. Patra}

Department of Agronomy, Bidhan Chandra Krishi Viswavidyalaya, Mohanpur, Nadia741252 (West Bengal), India

\section{S. Sardar}

Department of Agronomy, Bidhan Chandra Krishi Viswavidyalaya, Mohanpur, Nadia741252 (West Bengal), India

*Corresponding author. Email: kasturighosh1991@gmail.com

\begin{abstract}
A field experiment was carried out during the Kharif season of two consecutive years 2015 and 2016 at Instructional Farm, Jaguli, Bidhan Chandra Krishi Viswavidyalaya, Nadia, West Bengal with the focal objective to assess the effect of different weed control measures on yield of transplanted kharif rice, IET 4786. Experiment having 3 replications was conducted in Randomized Block Design with nine treatments, namely, $\mathrm{T}_{1}$ - Pendimethalin 30\% EC + Pyrazosulfuron ethyl $10 \%$ WP @ $675+15 \mathrm{~g}$ a.i, $\mathrm{T}_{2}$ - Pendimethalin $30 \%$ EC + Pyrazosulfuron ethyl $10 \%$ WP @ $900+200 \mathrm{~g}$ a.i, $\mathrm{T}_{3}$-Pendimethalin 30\% EC +Pyrazosulfuron ethyl $10 \%$ WP @ $1125+25 \mathrm{~g}$ a.i, T4-Pendimethalin 30\% EC @ 1500 g a.i, $T_{5}$ - Pyrazosulfuron ethyl $10 \%$ WP @ $15 \mathrm{~g}$ a.i, $\mathrm{T}_{6}$ - Pyrazosulfuron ethyl $10 \%$ WP @ $20 \mathrm{~g}$ a.i, T $7^{-}$Metsulfuron methyl $10 \%$ + Chlorimuron ethyl $10 \%$ WP @ $4 \mathrm{~g}$ a.i, T $8^{-}$ Hand weeding and $\mathrm{T}_{9}$ - Weedy check. Significant variations were observed on the mixed weed flora as well as onperformance of rice under the different herbicidal treatments.Pendimethalin 30\% EC + Pyrazosulfuron ethyl 10\% WP @ 1125+25 g a.i) was found to be the most effective recording the lowest weed population and weed dry weightwith the highest weed control efficiency ( $83.5 \%$ in 2015 and $79.8 \%$ in 2016) and the highest number of panicles $\mathrm{m}^{-2}$ (215.1 in 2015 and 231 in 2016), number of filled grains panicle ${ }^{-1}$ (85.39 in 2015 and 115.47 in 2016) and grain yield of rice (3.60 t/ha in 2015 and $5.30 \mathrm{t} /$ ha in 2016). The lowest grain yield(2.20 t/ha in 2015 and $3.40 \mathrm{t} / \mathrm{ha}$ in 2016) and the highest weed density were observed in weedy check plots.
\end{abstract}

Keywords: Herbicide, Kharif rice, Weed density, Weed control efficiency, Yield

\section{Article Info}

DOI:10.31018/jans.v10i2.1772 Received: February 27, 2018

Revised: April 12, 2018

Accepted: May 8, 2018

How to Cite

Ghosh, K. et al. (2018). Weed Management in kharif rice in new alluvial zone of West Bengal. Journal of Applied and Natural Science, 10(2): $716-722$

\section{INTRODUCTION}

Rice (Oryza sativa L.) is considered as the most important food crop and feeds more than 60 percent of population in India. In India, the area under rice is $43.86 \mathrm{~m}$ ha with a production of almost $104.80 \mathrm{~m}$ ton and productivity being $2390 \mathrm{~kg} \mathrm{ha}^{-1}$ (FAO, 2017).

Rice production in India has increased during the last 61 years by nearly $400 \%$ from 1950 to 2015 . Major share of rice production is in kharif season. Rice is grown well in hot and moist climate. It requires an optimum temperature range of $16^{\circ} \mathrm{C}-$ $27^{\circ} \mathrm{C}$ and rainfall of $100 \mathrm{~cm}$ to $200 \mathrm{~cm}$. Rice can be grown in all type of soils like light to heavy soil, except very sandy but clay soil is the best for rice cultivation (Mahajan et al, 2009). Among the different states, West Bengal is the leading state, which contributes $16.4 \%$ to all India production of rice and occupies first position in terms of production and area. The increase in productivity of rice is due to introduction of high yielding varieties and hybrids like MTU 7029, IET 9947, IET 4786, IET 4094, IET 1444, IET 5656, KRH 2, DRRH 2, etc. which are responsive to good fertilizer management coupled by improved package of practices evolved by agriculture scientists for various regions. To achieve huge demand of consumer needs and achieving the target of daily diet for every Indian is a massive challenge as we have it despite of shrinking land and water resource, out dated technologies, increasing cost of labour and 
input as well. Though ranking first in area and second in production, our country ranks $51^{\text {st }}$ in productivity. India has to produce $135-145$ million tonnes of rice by 2020 to feed the additional 350 million people (Prakash et al., 2008). So, there is a large scope for increase in productivity.

Weeds are one of the major obstacles for getting optimum rice production because of their ability to compete for space, moisture, sunlight and nutrients. Uncontrolled growth of weeds in paddy reduced the grain yield by $75.8,70.6$ and 62.6 percent in dry seeded rice, wet seeded rice and transplanted rice, respectively (Singh et al., 2005). The diverse weed population under transplanted paddy conditions (grasses, sedges and broadleaved weeds) can cause yield reduction up to 76 percent (Mishra et. al, 2007). About 60 percent of the weeds emerge during 7-30 days after transplanting and strongly compete with rice (Saha and Rao, 2010).

The most widely used method of controlling weeds is use of herbicides. Sulfonylurea herbicides are widely used in India in number of crops like wheat and rice. Several pre-emergence herbicides like butachlor, propanil, oxyfluorfen, pendimethalin, etc. have been tried to control weeds in direct seeded and transplanted paddy (Sheeja et. al, 2013). Singh et. al (2005) reported that out of total gross cultivated area in India, only $15 \mathrm{~m}$ ha are currently treated with herbicides. Farmers generally apply herbicides by mixing them in sand for easy operation and prefer to use either single application of PRE or POST herbicides which fails to control diverse weed flora observed in direct seeded rice and transplanted rice (Chauhan, 2012; Chauhan and Opeña, 2012). However, it is important to use a broad-spectrum herbicide program including PRE and POST herbicides for season-long effective weed control and to avoid shifts toward problematic weed species (Chauhan, 2012; Yadav et al., 2009) or evolution of herbicide -resistant weed biotypes. Lower weed biomass as well as high grain yield in paddy was recorded in cyhalofop+chlorimuron+metsulfuron followed by fenoxaprop+ chlorimuron+metsulfuron (Menon et al., 2014). Herbicide combinations judiciously chosen gives effective weed control than single herbicide application (Khaliq et al, 2012)

With the above ideas, an experiment was carried out at University Instructional farm, Jaguli, Bidhan Chandra Krishi Viswavidyalaya during kharif season in 2015-'16 to study the effect of different herbicides and herbicidal combinations along with varied doses on yield of transplanted kharif rice.

\section{MATERIALS AND METHODS}

A field experiment was carried out at University Instructional farm, Jaguli, Bidhan Chandra Krishi Viswavidyalaya, West Bengal, India, during kharif season in two consecutive years of 2015 and
2016 to assess the effect of different weed control measures on yield of transplanted kharif rice, IET 4786. The farm is situated very close to Tropic of Cancer having approximately $22.93^{\circ} \mathrm{N}$ latitude and $88.53^{\circ} \mathrm{E}$ Longitude with an average altitude of 9.75 meters above mean sea level (MSL). The climate of this region is tropical humid. Summers are hot and winter are moderate. Southwest monsoon breaks in the first week of June and ceases during third week of October. The average annual rainfall received by this area is around $1600 \mathrm{~mm}$, out of which around $1300 \mathrm{~mm}$ occurs in monsoon. The average range of temperature varies from 25 $-36^{\circ} \mathrm{C}$ in summer and $10-25^{\circ} \mathrm{C}$ in winter. The soil of the experimental plots were analyzed in the laboratory following the standard methods of estimation (Walkley and Black, 1934, Jackson, 1967). The soil of the experimental field was sandy loam in texture (sand, silt and clay content is 54.1, 21.2 and $24.7 \%$ respectively) with medium fertility status, neutral in reaction $(\mathrm{pH}-6.9)$ with $0.54 \%$ organic carbon, $0.057 \%$ total nitrogen, $16.45 \mathrm{~kg} \mathrm{ha-}$ available phosphorus and $186.33 \mathrm{~kg} \mathrm{ha}^{-1}$ available potassium. Experiment having 3 replications were conducted in Randomized Block Design (RBD) with nine treatments, namely, $\mathrm{T}_{1}$ - Pendimethalin 30\% EC + Pyrazosulfuron ethyl $10 \%$ WP @ $675+15 \mathrm{~g}$ a.i, $\mathrm{T}_{2}$ - Pendimethalin 30\% EC + Pyrazosulfuron ethyl $10 \%$ WP @ $900+200 \mathrm{~g}$ a.i, $\mathrm{T}_{3}$ - Pendimethalin 30\% EC + Pyrazosulfuron ethyl $10 \%$ WP @ 1125 + 25 g a.i, $\mathrm{T}_{4}$ - Pendimethalin 30\% EC @ $1500 \mathrm{~g}$ a.i, T5-Pyrazosulfuron ethyl 10 \% WP @ $15 \mathrm{~g}$ a.i, T6- Pyrazosulfuron ethyl $10 \%$ WP @ $20 \mathrm{~g}$ a.i, $\mathrm{T}_{7}$ - Metsulfuron methyl $10 \%+$ Chlorimuron ethyl 10 \% WP @ 4 g a.i, T T- Hand weeding and $\mathrm{T}_{9}$ - Weedy check as control plot. All herbicide combinations were applied at 3 days after transplanting (DAT).

The crop was sown in three different dates with the seed rate of $80 \mathrm{~kg} \mathrm{ha}^{-1}$ and spacing of $20 \mathrm{~cm} \times$ $15 \mathrm{~cm}$ was followed in plot size of $4 \mathrm{~m} \times 5 \mathrm{~m}$. The crop was transplanted on 20/08/2015 and $22 / 08 / 2016$. The N, P and $\mathrm{K}$ dose used in this experiment was $60: 30: 30$ respectively. Full dose of $P$ and $\mathrm{K}$ and half of $\mathrm{N}$ applied at the time of final land preparation, and remaining half nitrogen given after first hand weeding where lifesaving irrigation was also given. The fertilizers used for this experiment were urea, single superphosphate (SSP) and muriate of potash (MOP). Excluding weed management practice, all the recommended improved package of practice was followed in this experiment.

Hand weeding was taken up twice at 15 DAT\& 30 DAT for second season. Knapsack sprayer with a flat fan nozzle was used in a spray volume of 375 $\mathrm{L} \mathrm{ha}^{-1}$. Observations were taken as species wise weed control efficacy andtheir dry weights $\left(\mathrm{g} / \mathrm{m}^{2}\right)$ from a composite sample (collected from 3 different spots per treatment) were recorded at 45 and 
75 days after application (DAA) along with the population of the weed flora using $1 \mathrm{~m} \times 1 \mathrm{~m}$ quadrate three times per plot for each observation and the average calculated data were presented on $\mathrm{m}^{-2}$ basis at 45 and 75 days after application (DAA). The yield attributes like number of panicles $\mathrm{m}^{-2}$, number of filled grains panicle $\mathrm{e}^{-1}$, test weight and grain yield $\left(\mathrm{t} \mathrm{ha}^{-1}\right)$ was recorded at harvest. $B: C$ ratio was calculated.

Weed control efficiency was calculated based on the data recorded $45 \& 75$ DAA as per the formula given below (Equation 1):

Weed Control Efficiency $(\%)=$ WDC - WDT $x$ WDC $\times 100$ ...Eqn (1)

Where, WDC $=$ Weed dry weight in untreated control, $\mathrm{g} / \mathrm{m}^{2}$

WDT $=$ Weed dry weight in treated plot, $\mathrm{g} / \mathrm{m}^{2}$

The data collected were subjected to statistical analysis by the analysis of variance method (Panse and Sukhatme, 1978) and the significance of different sources of variations were tested by error mean square by Fisher and Snedecor's F test at the probability level 0.05 . For the determination of critical difference at 5\% level of significance, Fischer and Yate's table was consulted. The Standard Error Mean (S.Em) and the value of critical difference (CD) to compare the differences between means were presented in the tables of results.

\section{RESULTS AND DISCUSSION}

Weed flora in the experimental field: Experimental plots were dominated with a mix weed flora of grasses, sedges and broadleaf weeds. Among the grassy weeds the major abundance is of Echinochlo acolona, whereas sedges population was predominated by Cyperus iria, and Cyperus difformis. In case of broadleaf weeds, Marselia quadrifolia, Alternenthera sessalis, Eclipta alba, Ludwigia purviflora and Monochoria vaginalis were observed in adundance.

Weed density: The different weed control measures including the herbicidal combinations had a profound effect on major weeds and their density per sq. $m$ area. At $45 \mathrm{DAA}$, the lowest population of Echinochloa colona(nil) was recorded from plots treated with Pendimethalin 30\% EC + Pyrazosulfuron ethyl 10\% WP @ 1125+25 g a.i ( $T_{3}$ treatment) which is significantly lower $(0.00$ per $\mathrm{m}^{2}$ in both 2015 and 2016) than all other treatments in both the years of experimentation. The highest population of $E$. colona was recorded from weedy check $\left(T_{9}\right)$ plot where no herbicides were applied (4.00 per $\mathrm{m}^{2}$ in 2015 and 5.44 per $\mathrm{m}^{2}$ in 2016, respectively).

In case of broadleaf weeds, similar trend was observed where $\mathrm{T}_{3}$ treatment (with Pendimethalin $30 \%$ EC + Pyrazosulfuron ethyl 10\% WP @ $1125+25 \mathrm{~g}$ a.i) recorded the significantly lower number of Marselia quadrifolia, Alternenthera

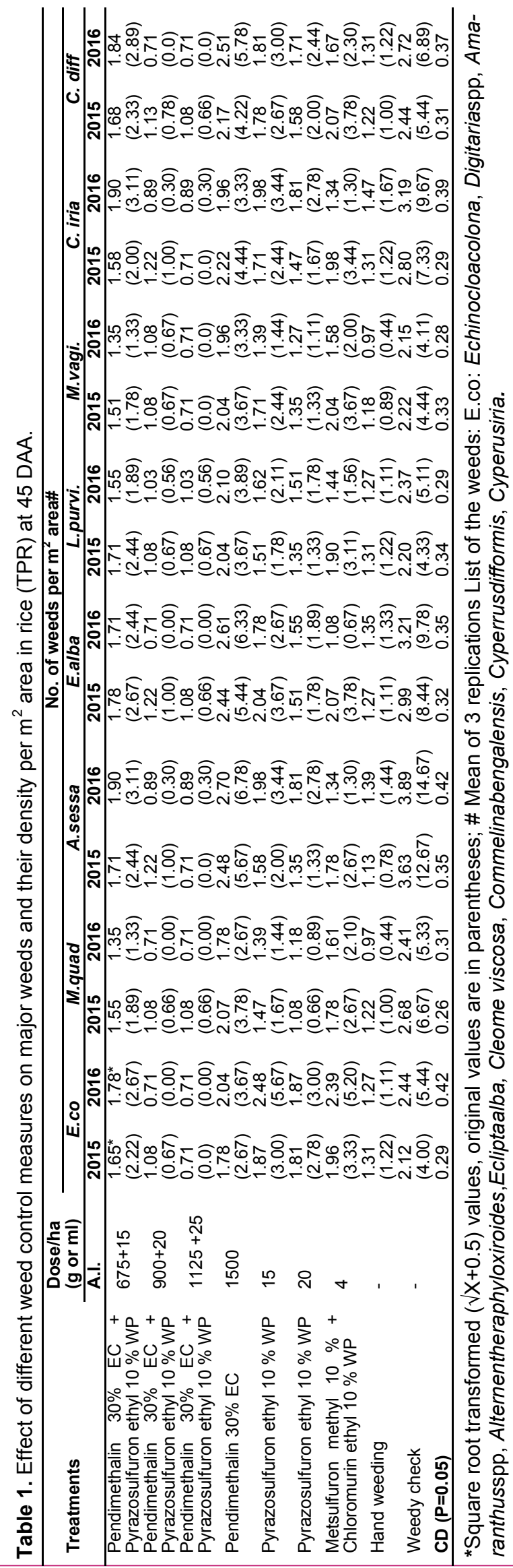


Ghosh K. et al. / J. Appl. \& Nat. Sci. 10 (2): 716 - 722 (2018)

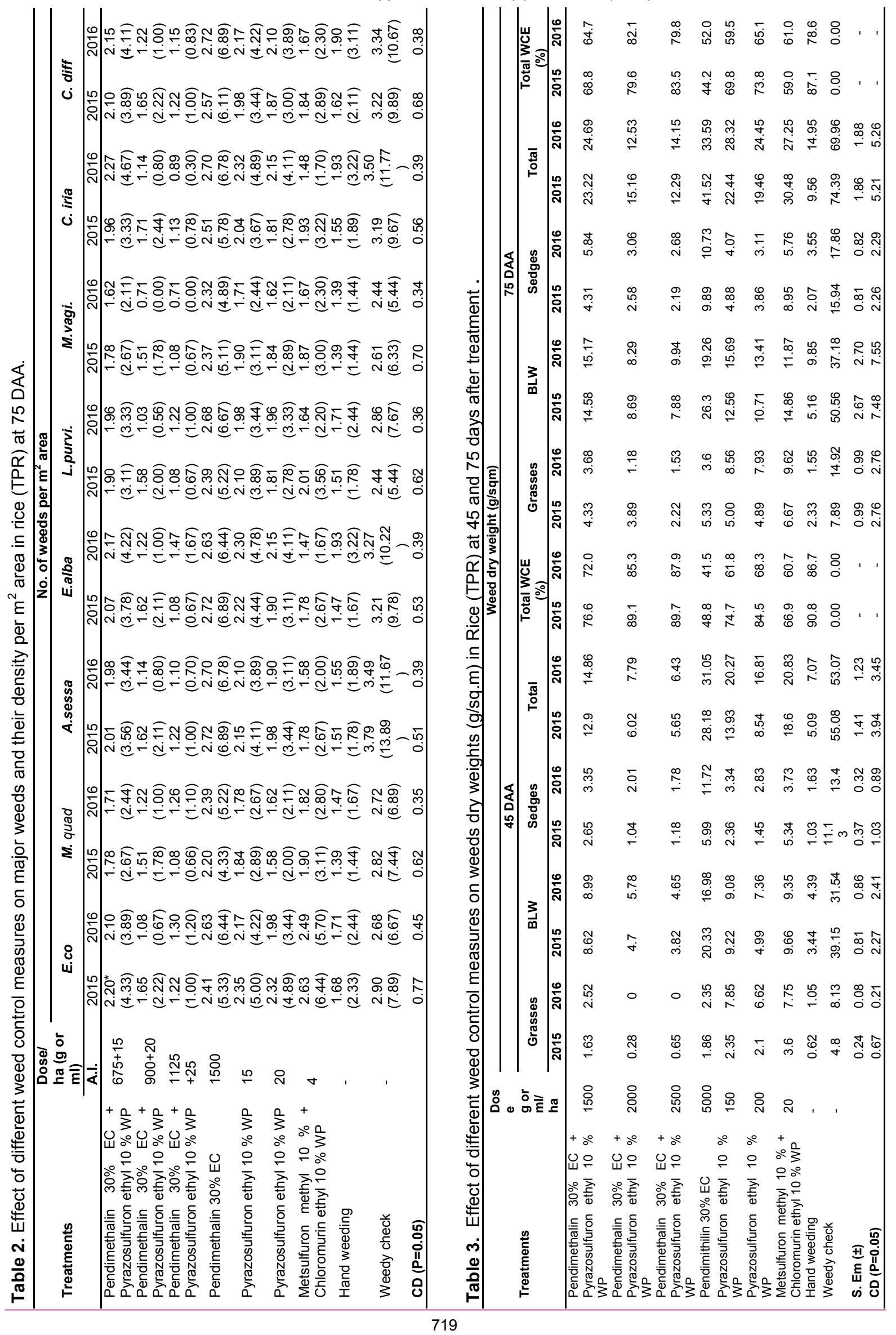


Ghosh K. et al. / J. Appl. \& Nat. Sci. 10 (2): 716 - 722 (2018)

Table 4. Effect of different weed control measure on yield attributes and yield of rice (TPR).

\begin{tabular}{|c|c|c|c|c|c|c|c|c|c|c|}
\hline \multirow[t]{2}{*}{ Treatments } & \multicolumn{2}{|c|}{$\begin{array}{l}\text { No. of panicle } \\
\mathrm{m}^{-2}\end{array}$} & \multicolumn{2}{|c|}{$\begin{array}{l}\text { No. of filled } \\
\text { grains panicle } e^{-1}\end{array}$} & \multirow{2}{*}{$\begin{array}{l}\begin{array}{l}\text { Test } \\
\text { (g) }\end{array} \\
2015 \\
\end{array}$} & \multirow{2}{*}{$\begin{array}{r}\text { weight } \\
2016\end{array}$} & \multicolumn{2}{|c|}{$\begin{array}{l}\text { Grain Yield } \\
\left(\mathrm{t} \mathrm{ha}^{-1}\right)\end{array}$} & \multicolumn{2}{|c|}{ B:C ratio } \\
\hline & 2015 & 2016 & 2015 & 2016 & & & 2015 & 2016 & 2015 & 2016 \\
\hline $\begin{array}{l}\text { Pendimethalin } 30 \% \text { EC + Py- } \\
\text { razosulfuron ethyl } 10 \% \text { WP }\end{array}$ & 175 & 193.4 & 101.22 & 126.89 & 19.42 & 19.56 & 3.44 & 4.80 & 2.08 & 2.59 \\
\hline $\begin{array}{l}\text { Pendimethalin } 30 \% \text { EC + Py- } \\
\text { razosulfuron ethyl } 10 \% \text { WP }\end{array}$ & 191.75 & 219.3 & 96.96 & 120.49 & 19.47 & 19.68 & 3.62 & 5.20 & 2.16 & 2.77 \\
\hline $\begin{array}{l}\text { Pendimethalin } 30 \% \text { EC + Py- } \\
\text { razosulfuron ethyl } 10 \% \text { WP }\end{array}$ & 215.1 & 231 & 85.39 & 115.47 & 19.6 & 19.87 & 3.60 & 5.30 & 2.12 & 2.78 \\
\hline Pendimithilin $30 \%$ EC & 160.5 & 181.3 & 97.15 & 133.70 & 19.24 & 19.39 & 3.00 & 4.70 & 1.80 & 2.52 \\
\hline $10 \%$ WP & 170.1 & 186 & 103.14 & 130. & 19.38 & & 3. & 4.75 & 2.10 & 2.62 \\
\hline Pyrazosulfuron ethyl $10 \%$ WP & 184.23 & 208.2 & 99.63 & 120.82 & 19.34 & 19.52 & 3.55 & 4.91 & 2.18 & 2.68 \\
\hline $\begin{array}{l}\text { Metsulfuron methyl } 10 \%+ \\
\text { Chloromurin ethyl } 10 \% \mathrm{WP}\end{array}$ & 167.6 & 188 & 97.13 & 134.76 & 19.35 & 19.46 & 3.15 & 4.93 & 1.94 & 2.71 \\
\hline Hand weeding & 221.2 & 240. & 86.01 & 115.5 & 19. & 19. & 3. & 5.45 & 2.05 & 2.69 \\
\hline Weedy check & 148.19 & 167.8 & 76.80 & 104.02 & 19.33 & 19.48 & 2.20 & 3.40 & - & - \\
\hline S. Em & 4.06 & 4.63 & 2.9 & 3.54 & 1.23 & 1.35 & 0.2 & 0.51 & - & - \\
\hline$C D(P=0.05)$ & 11.57 & 13.2 & 8.34 & 10.1 & NS & NS & 0.58 & 1.44 & - & - \\
\hline
\end{tabular}

sessalis, Eclipta alba, Ludwigia purviflora and Monochoria vaginalis in both the years of experimentation $\left(0.66,0.00,0.66,0.67\right.$ and 0.00 per $\mathrm{m}^{2}$ respectively in 2015 and $0.00,0.30,0.00,0.56$ and 0.00 per $\mathrm{m}^{2}$ respectively in 2016). The highest population of Marselia quadrifolia, Alternenthera sessalis, Eclipta alba, Ludwigia purviflora and Monochoria vaginalis was observed in weedy check $\left(\mathrm{T}_{9}\right)$ plot $(6.67,12.67,8.44,4.33$ and 4.44 per $\mathrm{m}^{2}$ in 2015 and $5.33,14.67,9.78,5.11$ and 4.11 per $\mathrm{m}^{2}$ in 2016).

In case of sedges, again $\mathrm{T}_{3}$ treatment (with Pendimethalin 30\% EC + Pyrazosulfuron ethyl 10\% WP @ $1125+25 \mathrm{~g} \mathrm{a.i}$ ) applied at a dose of $2500 \mathrm{ml}$ recorded the significantly lower number of $C$. iria and C. difformis in 2015 and 2016 (0.00 per $\mathrm{m}^{2}$ and 0.66 per $\mathrm{m}^{2}$ in 2015 and 0.30 per $\mathrm{m}^{2}$ and 0.00 per $\mathrm{m}^{2}$ in 2016 respectively). Weedy check $\left(T_{9}\right)$ recorded significantly highest number of sedges, C. iria recorded 7.33 per $\mathrm{m}^{2}$ and 9.67 per $\mathrm{m}^{2}$ and C. difformis recorded 5.44 per $\mathrm{m}^{2}$ and 6.89 per $\mathrm{m}^{2}$ in 2015 and 2016 respectively. At 45DAA, $\mathrm{T}_{3}$ treatment proved superior to all other herbicidal combinations and hand weedings, since the mixed weed flora was effectively checked by with Pendimethalin 30\% EC + Pyrazosulfuron ethyl 10\% WP @ 1125+25 g a.i (table 1).

At 75 DAA, $T_{3}$ treatment (Pendimethalin 30\% EC + Pyrazosulfuron ethyl 10\% WP @ 1125+25 g a.i) continued to show its superior effectiveness in controlling grassy, sedge and BLW as compared to all other herbicidal treatments in both the years of experimentation. Lowest population of E. Colona was recorded (1.00 per $\mathrm{m}^{2}$ in 2015 and 1.20 per $\mathrm{m}^{2}$ in 2016) as well as lower number of Marselia quadrifolia ,Alternenthera sessalis, Eclipta alba, Ludwigia purviflora and Monochoria vaginalis in both the years of experimentation $\left(0.66,1.0,0.67,0.67\right.$ and 0.67 per $^{2}$ in 2015 and $1.10,0.70,1.67,1.0$ and 0.0 per $\mathrm{m}^{2}$ in 2016 ). Likewise, the significantly lowest sedge population was recorded (C. iris and $C$. difformis recorded 0.78 per $\mathrm{m}^{2}$ and 0.30 per $\mathrm{m}^{2}$ in 2015 and 1.00 per $\mathrm{m}^{2}$ and 0.83 per $\mathrm{m}^{2}$ in 2016 respectively). Weedy check $\left(T_{9}\right)$ recorded significantly highest population of grasses, sedges and BLW in both the years of experimentation (table 2).

Pendimethalin, being a dinitroaniline group herbicide inhibits root and shoot growth. It controls the weed population, mainly annual grasses and certain broadleaf weeds and prevents weeds from emerging, particularly during the crucial development phase of the crop. Its primary action mode is to prevent plant cell division and elongation in susceptible species (Chauhan and Johnson, 2011). Pyrazosulfuron ethyl, on the other hand, is a synthetically produced sulfonyl urea having broadspectrum activity, absorbed by roots and translocated throughout the weed plant body. It inhibits plant amino acid synthesis - acetohydroxyacid synthase (AHAS). Singh et. al., (2005) observed similar results and concluded the fact that combination of Pendimethalin 30\% EC and Pyrazosulfuron ethyl 10\% WP was effective in providing broad spectrum control over mix weed flora in rice field because of combining the two, since the former one is effective in controlling annual grasses and certain broadleaf weeds and latter gave broad spectrum control against grasses, sedges and BLWs, hence provided an overall control against weed flora.

Weeds dry weight and weed control efficiency (WCE): At 45 DAA, weed dry weights in rice varied significantly among various herbicidal treatments. $\mathrm{T}_{3}$ treatment (with Pendimethalin 30\% EC + Pyrazosulfuron ethyl 10\% WP @ 1125+25 g a.i) controlled mixed weed flora (grass, sedge and BLW) effectively and recorded lowest weed dry weights $(0.00,3.82,1.18 \mathrm{~g} / \mathrm{sq} . \mathrm{m}$ of grass, BLW and sedge in 2015 and $0.00,4.65,1.78 \mathrm{~g} / \mathrm{sq} . \mathrm{mof}$ grass, BLW and sedge in 2016, respectively) with total dry weight of mixed flora of $5.65 \mathrm{~g} / \mathrm{sq} . \mathrm{m}$ and $6.43 \mathrm{~g} / \mathrm{sq} . \mathrm{m}$ in 2015 and 2016 respectively.Weedy check $\left(T_{9}\right)$ recorded the highest weed dry weights of grasses, BLW and sedges in both the years of experimentation $(4.18,39.15,11.3 \mathrm{~g} / \mathrm{sq} . \mathrm{m}$ of grass, 
BLW and sedge respectively in 2015 and 8.13 , $31.54,13.4 \mathrm{~g} / \mathrm{sq} . \mathrm{m}$ of grass, BLW and sedge respectively in 2016) with total dry weight of mixed flora of 55.08 g/sq.m and 53.07 g/sq.m in 2015 and 2016 respectively. Highest weed control efficiency (WCE \%) was recorded by $\mathrm{T}_{3}$ treatment (with Pendimethalin 30\% EC + Pyrazosulfuron ethyl 10\% WP @ 1125+25 g a.i) with $89.7 \%$ and $87.9 \%$ WCE in 2015 and 2016, respectively.

At 75 DAA, similar trend was observed in case of weed dry weights. Highest dry weight was recorded in weedy check $\left(T_{9}\right)$ in both the years of experimentation. Lowest was recorded in $\mathrm{T}_{3}$ treatment (with Pendimethalin 30\% EC + Pyrazosulfuron ethyl 10\% WP @ 1125+25 g a.i).Lowest weed dry weights $(2.22,7.88,2.19 \mathrm{~g} / \mathrm{sq} . \mathrm{m}$ of grass, BLW and sedge in 2015 and 1.53, 9.94, $2.68 \mathrm{~g} / \mathrm{sq} . \mathrm{m}$ of grass, BLW and sedge in 2016, respectively) with total dry weight of mixed flora of $12.29 \mathrm{~g} / \mathrm{sq} . \mathrm{m}$ and $14.15 \mathrm{~g} / \mathrm{sq} . \mathrm{m}$ in 2015 and 2016 respectively and recorded the highest weed control efficiency of $83.5 \%$ and $79.8 \%$ in 2015 and 2016 respectively (table 3).Similar result was recorded by Kaur and Singh (2015) and Singh et. al. (2008).Combination of Pendimethalin $30 \%$ EC and Pyrazosulfuron ethyl $10 \%$ WP were effective in controlling both annual and perennial weeds (grasses, sedges and BLW) effectively as compared to other herbicidal combinations because of pre-emergence application of Pendimethalin which can manage all BLWs and has no adverse effect on rice flora and same goes for Pyrazosulfuron that manages grasses and sedges reducing the stress of riceweed competition during the critical crop-weed competition period of rice. Hence resulting in higher crop yields and low weed population, which ultimately led to high weed control efficiency in case of $\mathrm{T}_{3}$ treatment (Pendimethalin 30\% EC + Pyrazosulfuron ethyl 10\% WP @ 1125+25 g a.i) as mentioned above.

Yield attributes and yield of rice: Different weed control measure affected yield attributes like number of panicles $\mathrm{m}^{-2}$ and number of filled grains panicle $^{-1}$ significantly except test weight. $T_{8}$ (hand weeding) recorded highest number of panicles $\mathrm{m}^{-2}$ (221.2 in 2015 and 240.1 in 2016) in both the year of experimentation. It was followed by $T_{3}$ (Pendimethalin 30\% EC + Pyrazosulfuron ethyl 10\% WP @ 1125+25 g a.i) treatment (215.1 in 2015 and 231.0 in 2016) and the weedy check $\left(T_{9}\right)$ recorded the lowest panicles $\mathrm{m}^{-2}$ (148.9 in 2015 and 167.8 in 2016). Higher number of panicles $\mathrm{m}^{-2}$ in case of $T_{8}$ and $T_{3}$ treatments may be attributed to the fact that higher control of weed population resulted in low crop- weed competition for nutrients, space and light and thus, the crop gave more number of effective tillers as compared to weedy check. The number of filled grains panicle $^{-1}$ were highest in $T_{5}$ treatment (Pyrazosulfuron ethyl 10\% WP @ $15 \mathrm{~g}$ a.i) which recorded 103.14 in 2015 and 130.55 in 2016 and T7 (Metsulfuron methyl 10\% + Chloromuron ethyl $10 \%$ WP @ 4 g a.i) treatments that recorded filled grains panicle ${ }^{-1}$ as 97.13 in 2015 and 134.76 in 2016 and the lowest was observed as usual in the weedy check (76.80 in 2015 and 104.2 in 2016) treatment ( $\left.T_{9}\right)$. Test weights didn't vary significantly across all the treatments (table 4).

All the herbicide applications resulted in significantly higher grain yield compared to non-treated control. $T_{8}$ (hand weeding) recorded highest grain yield of $3.71 \mathrm{t} /$ ha and $5.45 \mathrm{t} / \mathrm{ha}$ in 2015 and 2016 respectively, followed by $\mathrm{T}_{2}$ (Pendimethalin $30 \%$ EC + Pyrazosulfuron ethyl 10\% WP @ $900+200$ $\mathrm{g}$ a.i) and $\mathrm{T}_{3}$ (Pendimethalin 30\% EC + Pyrazosulfuron ethyl 10\% WP @ 1125+25 g a.i) treatment which recorded grain yield of 3.62 and $3.60 \mathrm{t} / \mathrm{ha}$ in 2015 and 5.20 and 5.30 t/ha in 2016. Weedy check $\left(T_{9}\right)$ recorded the significantly lowest grain yield of 2.20 and 3.40 t/ha in 2015 and 2016 respectively (table 4). Similar observation was also made by Teja et al. (2015). The higher yield recorded from hand weeded plots and plots under herbicidal treatments are an outcome of effective weed control which resulted in less crop weed competition and lowest yield in weedy check may be attributed to the intense weed competition in the latter case.

$B$ : C ratio was recorded nil in case of weedy check $\left(T_{9}\right)$ owing to the fact that no weed control measures were adopted and benefit is considered negligible as compared to other treatments. Among the herbicidal treatments, lowest value of 1.80 in 2015 and 2.52 in 2016 was recorded by Pendimethalin $30 \% @ 15 \mathrm{~g}$ a.i $\left(\mathrm{T}_{4}\right)$.Highest value of B : Cratio of 2.12 in 2015 and 2.78 in 2016 was recorded by $\mathrm{T}_{3}$ (Pendimethalin $30 \% \mathrm{EC}+\mathrm{Py}$ razosulfuron ethyl 10\% WP @ 1125+25 g a.i) treatment followed by $\mathrm{T}_{2}$ treatment ( Pendimethalin 30\% EC + Pyrazosulfuron ethyl 10\% WP @ $900+200 \mathrm{~g}$ a.i). This is due the fact that $\mathrm{T}_{3}$ and $\mathrm{T}_{2}$ treatment effectively managed weed population and reduced crop-weed competition resulting in higher yield of rice and thus, higher $\mathrm{B}$ : $\mathrm{C}$ ratio. The use of in realizing high net returns was in conformity with Acharya and Bhattacharya (2013) and Patra et al. (2011). Thus, Pendimethalin 30\% EC + Pyrazosulfuron ethyl 10\% WP @ 1125+25 g a. i i.e. $\mathrm{T}_{3}$ treatment was found to be the most effective way in controlling mixed weed flora in transplanted kharif rice, IET 4786.

\section{Conclusion}

Kharif rice is usually dominated with a mix weed flora like: Echinochloa colona, Marselia quadrifolia,, Alternenthera sessalis, Eclipta alba, Ludwigia purviflora and Monochoria vaginalis, Cyperus iria, and Cyperus difformis. This study indicated that use of herbicides in combination may profitably replace the time consuming and expensive hand 
weeding for weed control in transplanted kharif rice in the near future. Pendimethalin $30 \% \mathrm{EC}+$ Pyrazosulfuron ethyl 10\% WP @ 1125+25 g a.i showed a broad spectrum management of both annual and perennial weeds. Pyrazosulfuron ethyl controls grasses and sedges effectively whereas Pendimethalin is effective against annual grasses and certains broad leaf weeds. The advantage of using herbicide combinations containing sulphonyl urea group herbicide like Pyrazosulfuron ethyl along with dinitroaniline group herbicide like Pendimethalin is that they provide overall control of mixed weed flora in rice fields without affecting crop yield negatively since thy are selective in action. So, this combination gives cost effective control over entire mixed weed flora in rice fields. Moreover they are synergistic in action to each other. Thus, this combination if applied can effectively control mixed weed flora of grass, sedge and BLWs in transplanted kharif rice, IET 4786.

\section{REFERENCES}

Acharya, S.S and Bhattacharya, S.P. (2013). Comparative efficacy of pyrazosulfuron ethyl and bentazon with acetamides for weed control in transplanted boro rice (Oryza sativa L.) in the lower gangetic plain zone of West Bengal, India. International Journal of Bio-resource and Stress Management. 4(4):506-509

Chauhan, B.S., (2012). Weed ecology and weed management strategies for dry seeded rice in Asia. Weed Technol. 26, 1e13.

Chauhan, B.S. and Johnson, D.E. (2011). Growth response of direct seeded rice to oxadiazon and bispyribac-sodium in aerobic and saturated soils. Weed Sci. 59: 119-122.

Chauhan, B.S., Opena, J., (2012). Effect of tillage systems and herbicides on weed emergence, weed growth, and grain yield in dry-seeded rice systems. Field Crops Res. 137, 56e69.

FAO. (2017). FAOSTAT Database FAO, Rome, www.faostat.fao.org (accessed June, 2017).

Jackson, M. L. (1967). In. Soil Chemical Analysis. Prentice Hall of India, Ltd., New Delhi

Khaliq, A., Matloob, A., Ahmad, N., Rasul, F. and Awan, I.U. (2012). Post-emergence chemical weed control in direct-seeded fine rice. Journal of Animal and Plant Sciences. 22(4): 1101-1106.

Mahajan, G., Chauhan, B.S. and Johnson, D.E. (2009). Weed management in aerobic rice in north westernindo-gangetic plains. J. Crop Improv. 23: 366-382.
Menon Syama S, Prameela P and Abraham C. T. 2014 Weed control in wet-seeded rice by post-emergence herbicides. Indian J. Weed Sci.46:169-71.

Sheeja., Raj, K., Nimmy Jose., Reena Mathew and Leenakumary, S. (2013). Chemical management of non-grassy weeds in direct-seeded rice. Indian Journal of Weed Science. 45(3): 159-162.

Mishra, J.S.,Dixit, A., Jay, G. and Varshney.(2007). Efficacy of penoxsulam on weeds and yield of transplanted rice (Oryza sativa). Indian Journal of Weed Science. 39 (1\&2): 24-27.

Panse, V. G. and Sukhatme, P. V. (1978). In Statistical Methods for Agricultural Workers ( $3^{\text {rd }}$ Ed.). Indian Council of Agricultural Rsearch, New Delhi.

Prakash H.C., Shekara B.G., Jahadeesh B.R., Kalayanmurthy K.N., Sivalingam M.L. (2008) Paddy pulse cropping system for sustaining soil health and rice yield in Cauvery command area. Res. on Crops.9 (1):7-9.

Patra, A.K., Halder, J and Mishra, M.M. 2011. Chemical weed control in transplanted rice in Hirakud command area of Orissa. Indian Journal of Weed Science. 43 (3\& 4): 175-177.

Kaur, S. and Singh, S. (2015). Bio-efficacy of different herbicides for weed control in direct-seeded rice. Indian Journal of Weed Science. 47(2): 106-109.

Saha, S. and Rao, K.S. 2010. Efficacy of metsulfuron methyl for controlling broadleaf weeds in transplanted rice (Oryzasativa) under rainfed shallow lowland.Indian J Agri Sci.80: 522-26.

Singh, S., Ladha, J.K., Gupta, R.K., Bhushan, L. and Rao, A.N. (2008). Weed management in aerobic rice systems under varying establishment methods. Crop Protec. 27: 660-671.

Singh, V. P., Singh, G., Singh, R.K., Singh, S. P., Kumar, A., Dhyani, V. C., Kumar, M. and Sharma, G. (2005). Effect of herbicides alone and in combination on direct seeded rice. Indian J. Weed Sci. 37:197201

Teja, K.C., Duary, B., Kumar, M. and Bhowmick, M.K. (2015). Effect of bensulfuronmethyl + pretilachlor and other herbicides on mixed weed flora of wet season transplanted rice. International Journal of Agriculture, Environment and Biotechnology. 8(2): 323-329.

Walkley, A. and Black, C. A. (1934). An examination of the different method for determining soil organic matter and proposed modification of the chromic acid titration method. Soil Sciences. 37(1): 29-38.

Yadav, D. B, Yadav, A. and Punia, S. S. (2009). Evaluation of bispyribac sodium for weed control in transplanted rice. Indian Journal of Weed Science. 41 (1 \& 2): 23-27. 